\title{
Investigating fuel and fireplaces with a combination of phytoliths and multi- element analysis; an ethnographic experiment
}

Carla Lancelotti $1, *, 2$

Email carla.lancelotti@upf.edu

Javier Ruiz-Pérez 1,3

Juan José García-Granero 1,4

1 Complexity and Socio-Ecological Dynamics Research Group

(CaSEs), Pompeu Fabra University, Mercé Rodoreda Building (Ciutadella Campus), Ramon Trias Fargas, 25-27, 08005 Barcelona, Spain

2 Department of Humanities, Pompeu Fabra University, Jaume 1 Building (Ciutadella Campus), Ramon Trias Fargas, 25-27, 08005 Barcelona, Spain

3 Department of Animal and Plant Biology and Ecology, Faculty of Biosciences, Autonomous University of Barcelona, C1-339, Campus Bellaterra, 08193 Barcelona, Spain

4 Department of Archaeology and Anthropology, Institución Milá y Fontanals, Spanish National Research Council (CSIC), c/Egipcíaques 15, 08001 Barcelona, Spain

\section{Abstract}

The identification of fuel-related practices in archaeological contexts is almost always associated with the identification of fire-related structures. Charcoal analysis is the standard method of identifying wood use in the past; however, in many circumstances wood was not the primary source of fuel. In arid and semi-arid environments alternative fuels such as dung, 
chaff and straw and, in general, plant processing by-products were predominant. The study of these types of fuel often necessitates the application of multi-proxy analyses, involving botanical micro-remains and geochemistry. This paper presents the results of an integrated analysis of phytoliths and chemical elements of samples collected in a modern ethnographic context, a domestic compound, in North Gujarat, India. Alternative fuels have been and are still very important in this area due to the scarcity of wood and the recent ban on cutting trees imposed by the government. Within the house studied, three fireplaces were present where different types of activities were performed selectively. The differential use of fuels in the three fireplaces is highlighted by the results of descriptive and multivariate statistics. However, the opposite geochemical signals that the fireplaces produced, when they should have been similar, would be difficult to interpret in an archaeological context where the practices that had produced such signals are unknown. The combination of phytoliths and geochemistry, coupled with the ethnographic information on the activity, can help us to construct better models to help interpret the archaeological record.

\section{Keywords}

Fuel

Phytoliths

Ethnography

Geochemistry

India

Anthropic activity markers

Communicated by L. Vrydaghs.

Electronic supplementary material

The online version of this article (doi:10.1007/s00334-016-0574-y) contains supplementary material, which is available to authorized users.

\section{Introduction}


Fire-related contexts, whether built structures or remains of scattered ashes, are among the most common features in archaeological contexts. These contexts offer detailed information on past activities, both domestic and industrial. Through the study of fire-related structures, archaeologists can gain insights on various aspects of human behaviour including technology, food consumption, resource use and, indirectly, on some aspects of the landscape and ecology in which a particular society developed its activities (Asouti 2003; Chabal 1997; Meyer 2003; Shahack-Gross et al. 2004). The identification of these contexts can sometimes be problematic, especially when the structure is not clearly identifiable during excavation. Very often, especially in urban societies, fire-related structures are easy to identify as they are built of permanent materials. On the contrary, in semi-permanent camps and small settlements such as hunter-gatherer sites, pastoral camps, etc., structures may not be easily identified. A common feature used to identify fireplaces in these contexts is the presence of fire-reddened sediments surrounding the fireplace. However, as highlighted by micromorphological studies conducted in Jandhala, the reddening is very limited in these contexts and the walls of the fireplaces show only minimal traces of it on their innermost faces (Yannitto 2011). In addition, there exists a series of contexts in which post-depositional processes hamper the identification of fire-related structures. We are here referring to all those situations in which the fire installation was built with the same materials that composed the floors and walls, such as mudbrick and wattle-and-daub structures. In arid, semi-arid and, to a certain extent, temperate prehistoric and historic contexts, buildings constructed of mudbricks are very common; however, our identification of such structures is hampered by their being extremely prone to degradation (Friesem et al. 2014). Beyond the recognition of firing structures, a further problem in the identification of fuel-related practices is represented by the choice of fuel that people used in the past. Wood was beyond any doubt the most common fuel in temperate and tropical contexts, though bone has been identified in a few cases as an alternative source of fuel (Beresford-Jones et al. 2010; Théry-Parisot 2002). However, in areas and contexts where wood is not easily available, people tend to revert to other types of resources; thus most often dung, crop-processing residues and small bushes are the primary source of fuel (Lancelotti 2010; Zapata Peña et al. 2003). These do not always leave significant macroscopic remains and need to be traced in the 
archaeological record by using specific techniques, which include (but are not limited to): phytoliths, chemical analysis, biomarkers, micromorphology and physical analyses (Shahack-Gross 2011). In addition, most often a multiproxy approach is needed in order to achieve the best results in identification (GurArieh et al. 2013; Lancelotti and Madella 2012; Linseele et al. 2013).

\section{Jandhala: the ethnographic context and the challenge of characterising fireplaces}

Jandhala is a farming village in North Gujarat, India, where most of the inhabitants still practise traditional non-mechanised farming and whose buildings are built from a mixture of mud and dung. In addition, fuels other than wood, especially dung in the form of dung cakes, are very important in the household economy and are frequently used. The vegetation around the area is scarce and the government banned the cutting of wood in order to try and preserve local plants (Lancelotti 2010). Recently the ban has been lifted for Prosopis juliflora [(Sw.) DC.] (mesquite), an exotic shrub or small tree which was introduced in the 1950s to counteract salinisation, which has since become invasive. Notwithstanding the availability of this fuel wood, people still use dung as their preferred fuel for cooking food that needs long slow burning fires.

Within the framework of the North Gujarat Archaeological Project (Madella et al. 2010), the authors conducted ethnographic work in 2009 and 2010 in a domestic compound that included two households. The floors and walls were built using a mixture of sand, cattle dung, clay and water; the plaster covering the main floor was composed of the same materials in different proportions, and had a thickness of ca. $2 \mathrm{~cm}$ and was renewed up to four times a year. Based on interviews with the owner of the house, the samples collected represent an accumulation of residues of about 10 years. The chemical signatures obtained are, therefore, an average of the residues that fell on the floor over that time; for a discussion of the use of samples that represent multiple events see Barba (1986) and Middleton et al. (2010). Analyses conducted on some of the samples collected inside the house were presented in Rondelli et al. (2014), where a full description of the ethnographic context is available. The present work stems from an interpretative challenge posed by that first study, where the geostatistical analysis of the samples revealed an 
inconsistency in the identification of fireplaces through multi-element geochemistry (Rondelli et al. 2014, Figs. 9, 10). The results of multi-element geochemistry, conducted with different combinations of elements and data analysis techniques such as principal component analyses (PCAs), deterministic interpolations and geostatistics, were inconsistent in the identification of the firing structures, leading to anomalies of opposite value. The authors claimed that these differences could be the results of differential uses of the fireplaces, two of which were in use at the time of the study and one was not, and by the use of different types of fuel in the inner fireplaces and the fireplace situated on the veranda (Rondelli et al. 2014, Figs. 1, 3). The present study tests whether phytoliths can be used as a proxy to confirm this hypothesis, and proposes a methodology of analysis of fireplaces that includes not only the residues of the firing activity but also the samples immediately surrounding the fire-related structure itself (García-Granero et al. 2015 ). Ethnography is particularly well placed to support this task as it provides an anchor to interpretation of the results. Considering the high degree of structure degradation that can be encountered in some archaeological contexts where the layout of the hearth or fireplace can be totally erased, results similar to those encountered in the case of the fireplaces at Jandhala can lead to misinterpretation of the archaeological evidence. Therefore, the possibility of interpreting the analytical results, knowing the exact context from which the samples were collected, provides strong support for methodological and analytical refinement. In this sense, we see ethnoarchaeology not as a way of creating parallelisms between the present and the past, but as a resource to fine-tune our methodological and analytical approach and for constructing robust methods, refining interpretations and inducing us to formulate new hypotheses.

\section{Materials and methods}

\section{Samples}

Samples were collected by inserting a hollow metal tube approximately $2 \mathrm{~cm}$ into the surface of the floor and collecting the sediment within, according to the methodology adopted in Rondelli et al. (2014). A total of 40 samples were analysed, including 3 fireplaces, each with 6 control samples from the floor surrounding the firing structures. Control samples were subsequently divided 
into inner and outer, according to their distance from the fireplace itself; an additional 19 floor samples were also analysed in order to test the similarities and dissimilarities in the samples. In addition, 22 samples of modern dung cakes, both fresh and ashed, from a previous study conducted in the region (Lancelotti and Madella 2012) were used in the statistical analyses to check whether the samples clustered according to their chemical and phytolith compositions. Figure 1 shows the location of the samples analysed; tables with raw data are provided, available for download, together with the $\mathrm{R}$ code used for statistical analysis, from an open source repository (http://github.com/c1379/papers_supl_materials/tree/master/Lancelotti2015impr).

\section{Fig. 1}

Plan of the domestic space analysed with indication of sample locations and the three different fireplaces with their respective control samples colour-coded

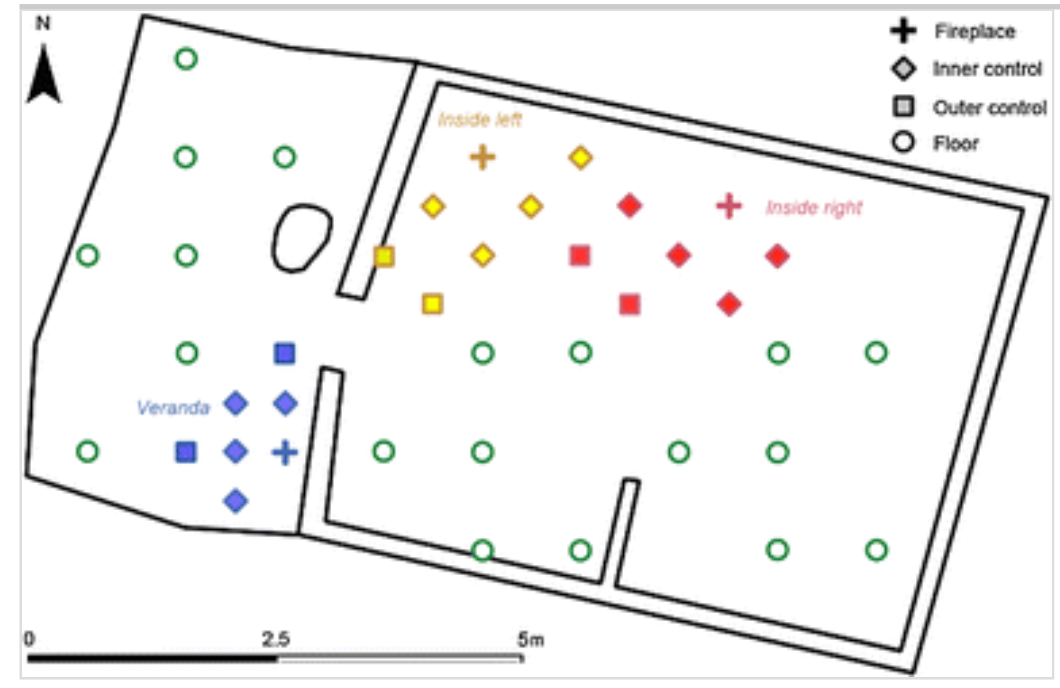

\section{Phytoliths}

Phytoliths were extracted from sediments using a method adapted from Madella et al. (1998). Preparations were permanently mounted in Entellan and the slides were studied under a Leica DM 2500 transmitted light microscope at $\times 200$ and $\times 630$ magnifications. Phytoliths were identified using published material (Pearsall et al. 2008; Piperno 2006) and with a reference collection of phytoliths from the leaves of local plants (Lancelotti 2010). A minimum of 350 single cell phytoliths were identified in each sample and multi-cell phytoliths (silica skeletons) were counted separately (Zurro 2011). For analysis, single morphotypes and short and long cells composing silica 
skeletons were grouped following Lancelotti and Madella (2012) into: (a) graminoids leaf/culm (elongate psilate, elongate sinuate and bulliforms), (b) graminoids inflorescence (elongate echinates and dendritics), (c) herbaceous indeterminate (herbaceous short cells of anatomical origin unknown), (d) woody taxa (tracheids, sclereids, scalloped and dicotyledonous irregular), and (e) indeterminate. The concentration of phytoliths per gram of acid insoluble fraction (AIF) was calculated according to Albert and Weiner (2001).

\section{Geochemistry}

Multi-element analysis of the samples, which were pre-treated with aqua regia digestion, was by inductive coupled plasma atomic emission spectroscopy, which was performed by ALS Laboratory Group, Seville, Spain. This method analyses the concentration of 35 elements, expressed in percent and parts per million, depending on the element; those elements that did not reach the reliable instrument detection limits in the majority of the samples were excluded from the analysis. In this study we used the same groups of chemical elements published in Rondelli et al. (2014) as indicative of dung and wood ash in order to be able to compare the results of the two studies. Wood was characterised by $\mathrm{Ca}, \mathrm{K}, \mathrm{Mg}, \mathrm{Al}$ and $\mathrm{P}$ and dung included $\mathrm{Al}, \mathrm{Ba}, \mathrm{Ca}, \mathrm{Co}, \mathrm{Cr}$, $\mathrm{Fe}, \mathrm{Mn}, \mathrm{Mo}, \mathrm{Ni}, \mathrm{Pb}$ and $\mathrm{P}$.

\section{Statistics}

Statistical analysis was carried out using free statistical software R (R Development Core Team 2014). The variables were standardised into percentages and normalised via $\log 10(+1)$ transformation. Analysis of variance (ANOVA) and multivariate ANOVA (MANOVA) were performed using the package Stats (R Development Core Team 2014) in order to test for significant differences in means between the groups previously described (ESM 1). PCA was performed on the datasets using the package FactoMineR (Lê et al. 2008) in order to examine the behaviour of the individuals (samples) and the variables (groups) through their ordination into significant dimensions. We only used the two first dimensions for the interpretation of results and eigenvalues; contribution of the variables (groups) in each component and coordinates of individuals (samples) are provided in ESMs 2 and 3. 


\section{Results}

Summaries of the phytolith and geochemistry results are given in Table 1. As mentioned in the "Samples" section, extensive supplementary material is available for downloading from an online open access repository.

Table 1

Summary of the phytoliths and geochemical analyses

\begin{tabular}{|c|c|c|c|c|c|}
\hline \multirow[b]{2}{*}{ Areas } & \multirow[b]{2}{*}{ Types } & \multicolumn{4}{|l|}{ Phytoliths } \\
\hline & & Concentration & $\begin{array}{l}\text { Graminoids } \\
\text { leaf/culm }\end{array}$ & $\begin{array}{l}\text { Graminoids } \\
\text { inflorescence }\end{array}$ & $\begin{array}{l}\text { Herb } \\
\text { indet }\end{array}$ \\
\hline \multirow{3}{*}{ Veranda } & Outer_control & $1,092,066$ & 6.63 & 1.78 & 86.25 \\
\hline & Inner_control & 883,792 & 8.07 & 3.35 & 80.12 \\
\hline & Fireplace & 966,850 & 10.90 & 4.67 & 77.88 \\
\hline \multirow{3}{*}{ Inside_left } & Outer_control & $1,148,302$ & 7.18 & 3.19 & 81.50 \\
\hline & Inner_control & $1,151,112$ & 13.04 & 2.81 & 76.42 \\
\hline & Fireplace & 119,056 & 19.15 & 3.65 & 70.82 \\
\hline \multirow{3}{*}{ Inside_right } & Outer_control & 902,626 & 7.50 & 2.00 & 86.67 \\
\hline & Inner_control & 514,262 & 9.98 & 1.98 & 80.05 \\
\hline & Fireplace & 213,991 & 9.62 & 2.88 & 76.60 \\
\hline Floor & & $2,981,254$ & 12.87 & 3.14 & 76.73 \\
\hline
\end{tabular}

All values, except phytolith concentration, are given as percentages. Phytolith concen phytoliths per gram of acid insoluble fraction (AIF) The full dataset is available for di http://github.com/cl379/papers_supl_materials/tree/master/Lancelotti2015impr

\section{Phytoliths}

\section{Concentration}

Overall concentration differences amongst the samples are present as indicated by the MANOVA results ( $<<0.05$, ESM 1$)$; however, when looking at each single fireplace no significant differences are highlighted between the fireplace and its control samples by the ANOVA results $(p=0.2$ for 
Inside_right, 0.7 for Inside_left and 0.5 for Veranda). Nevertheless, clear patterns emerge from the analysis of concentration: general floor samples have higher concentration and variability than fireplaces, including their control samples (Fig. 2). Among the fireplaces, the one currently in use inside the house (Inside_right) is the one with the lowest concentration of phytoliths (Fig. 3).

Fig. 2

Differences in phytolith concentrations between the groups of samples under study. Notice that the three fireplaces (Inside_left, Inside_right and Veranda) display a concentration lower than those of floor samples and of the outer_controls and that floors have a much higher variability than the control samples

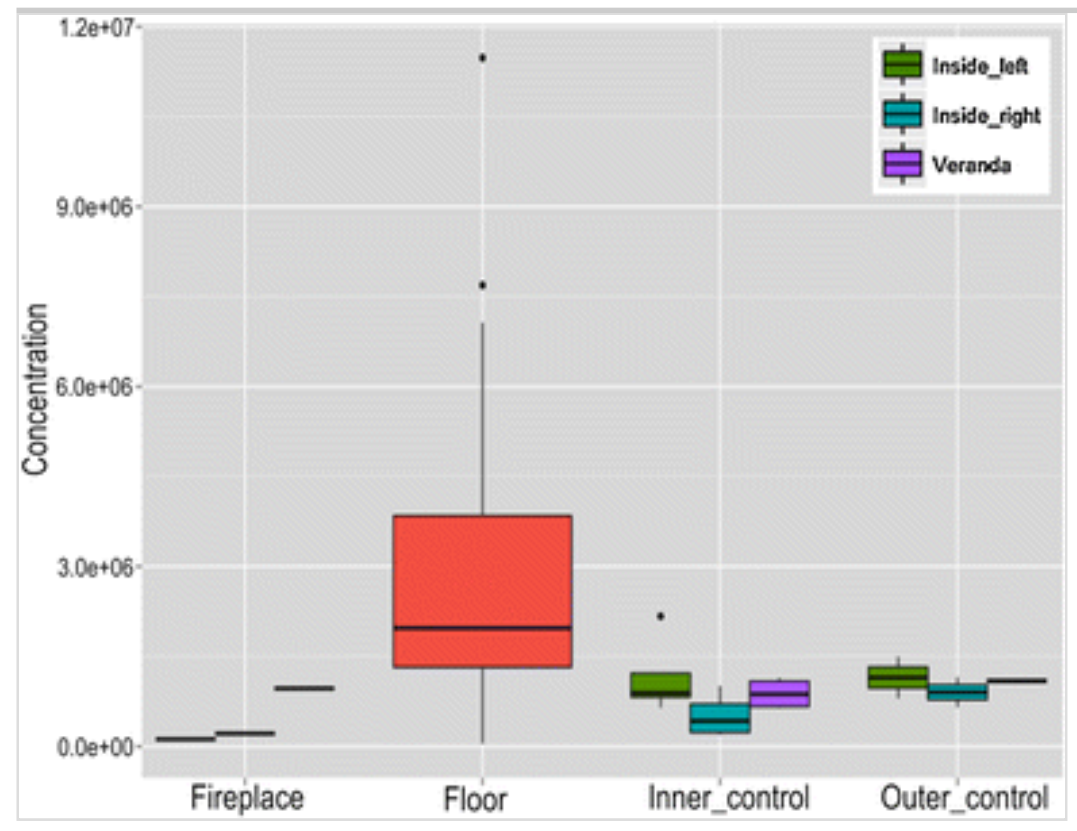

Fig. 3

Differences in phytolith concentrations within the groups of samples under study. Notice that the three fireplaces (Inside_left, Inside_right and Veranda) include both the fireplace and the control samples 


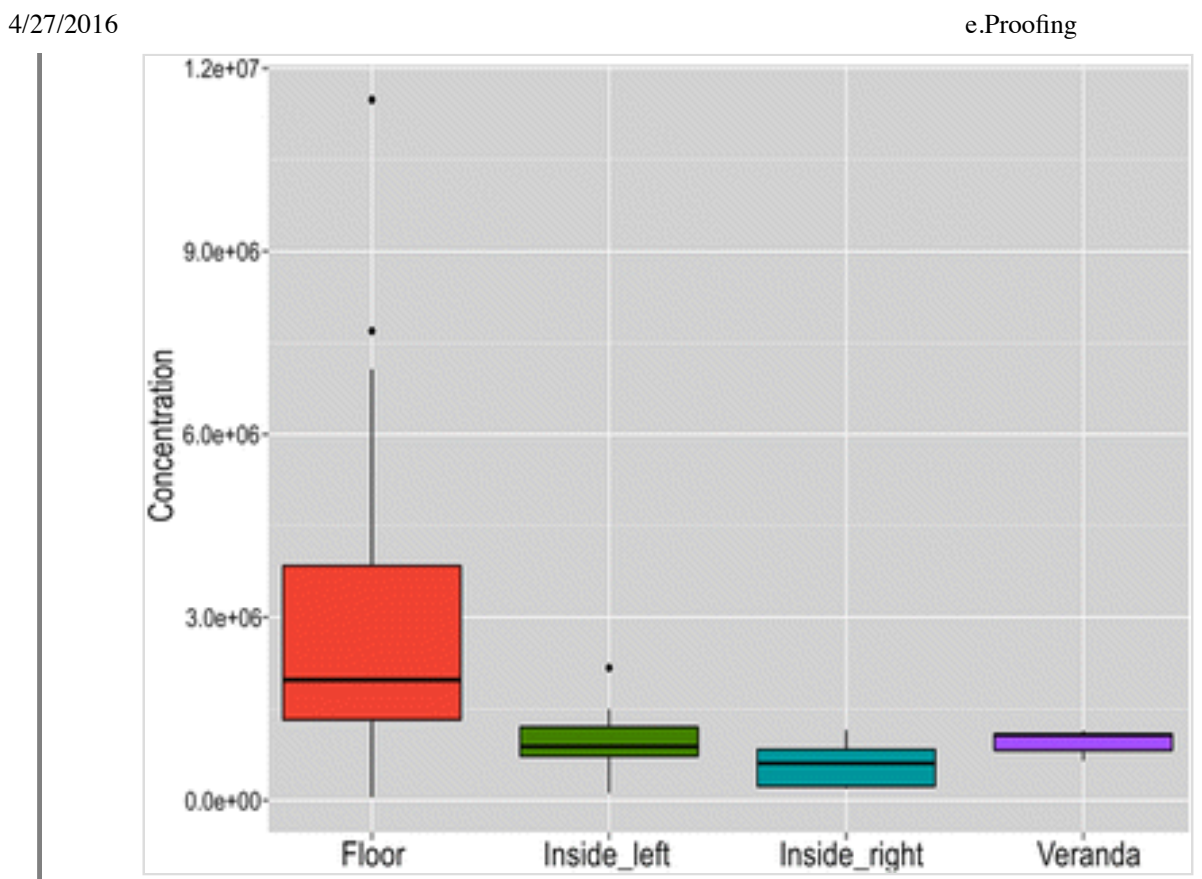

\section{Taphonomy}

Considering the short deposition time, taphonomy should not have had a great impact on the assemblages under study. However, repetitive sweepings of the floor can damage the phytoliths and change the assemblages. An analysis of the average number of cells per silica skeleton indicates that physical breakage is slightly higher in the two fireplaces in use, at 2.37 in the veranda and 2.08 in the inner hearths, than in the general floor sediments (3.27) and in the fireplace not currently in use (5.98).

\section{Morphological analysis}

A total of 37 different morphotypes were identified during the analysis and subsequently grouped for the specific aims of this work into the taxonomical groups specified above. All samples had over $70 \%$ of indeterminate herbaceous morphotypes, which clearly indicates that grasses represent the primary input of phytoliths into the samples. The three fireplaces show a similar morphological composition, except in respect to woody dicotyledonous morphotypes, which are higher in the veranda fireplace and not present in the two interior hearths (Fig. 4). The three fireplaces show different trends in morphological composition regarding their controls: (a) the Inside_right fireplace shows lower percentages of grass leaf or culm, grass inflorescence and woody plant morphotypes than its controls, (b) the Inside_left hearth has a larger quantity of leaf/culm, lower values of woody 
dicotyledonous and inflorescence higher than the inner_controls but lower than the outer_controls, and (c) the veranda fireplace has a higher concentration of leaf/culm and inflorescence morphotypes, but lower values of woody dicotyledonous ones in respect to both inner_and outer_controls. The two fireplaces in use, Veranda and Inside right, showed a difference in the distribution of woody dicotyledonous morphotypes within the control samples, which are more concentrated in the inner_control than in the outer_control samples in the case of the hearth inside the house and vice versa in the veranda fireplace. Inflorescence morphotypes are more frequent in the floor samples, and show values similar to the control samples (inner and outer) of the inner fireplace which was not in use (Inside_left).

\section{Fig. 4}

Bar chart of the morphotypological phytolith groups observed in the samples. Indeterminate herbaceous type have been excluded as they constituted over $70 \%$ of the samples, impairing the understanding of differences

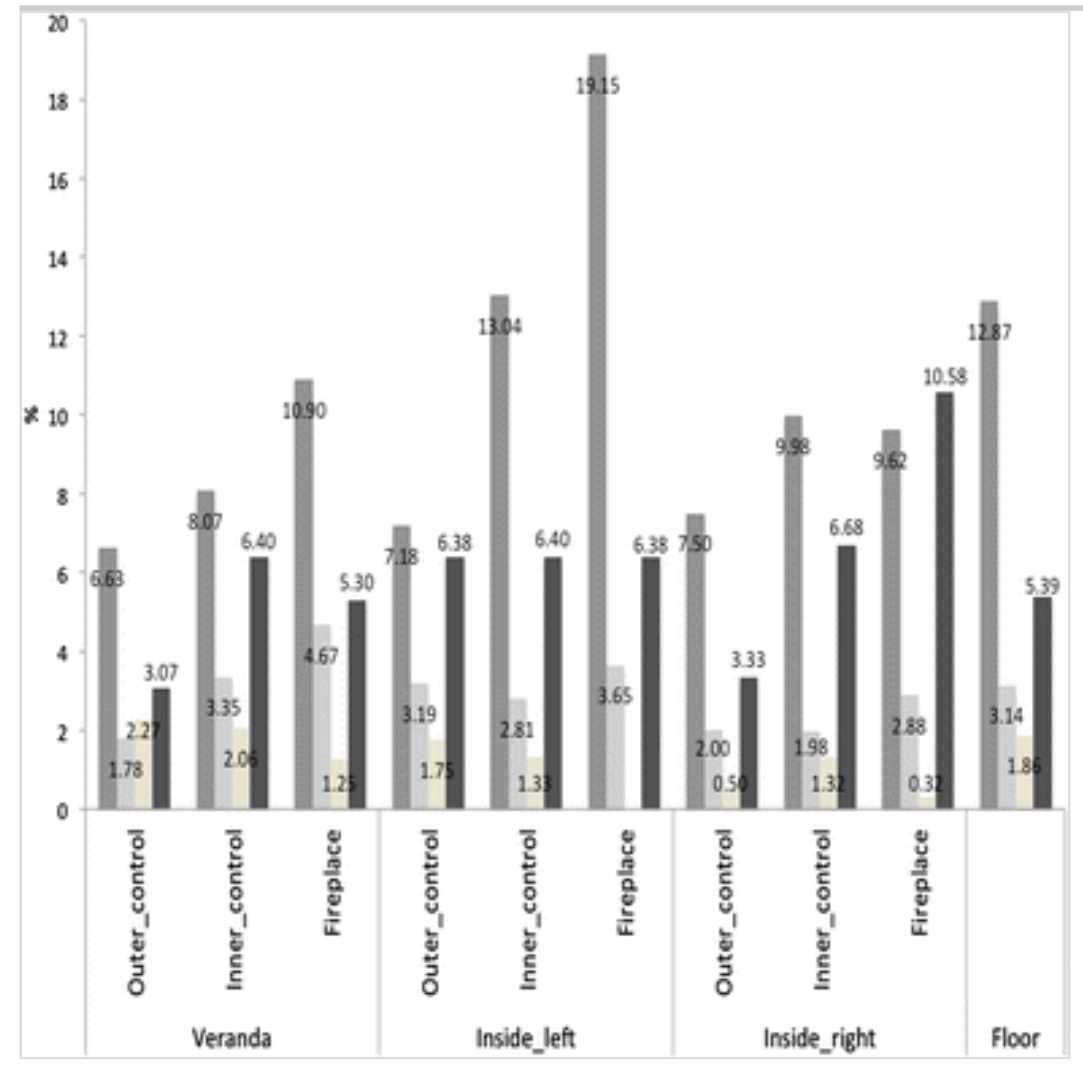

\section{Multi-element geochemistry}

Figure 5 shows the composition of samples in relation to the dung and wood 
groups. In accordance with the previous results, the fireplace situated in the veranda showed a peak of dung signature compared with the other two fireplaces. Interestingly this fireplace also shows the highest peak in wood ash elements. The difference between the fireplaces and their control samples is noteworthy: in the case of the two inner fireplaces, elements are less concentrated in the fireplace than in the control samples, whereas the veranda hearth has higher values than its control samples. In general, control samples had the same levels of both dung and wood ash elements as the floor samples, both inside the house and in the veranda.

\section{Fig. 5}

Bar chart of the wood and dung chemical groups

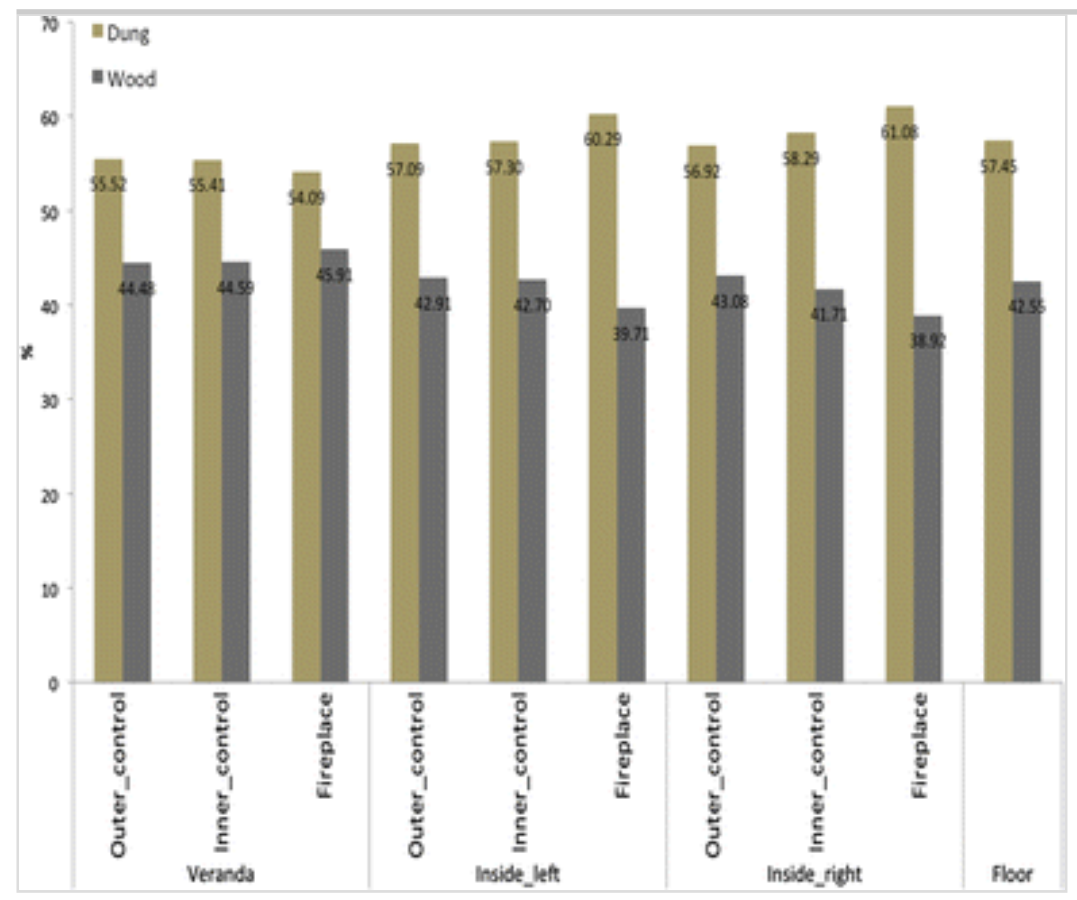

\section{Integration of data}

PCA was performed only on phytoliths and on phytolith and chemical elements groups, both including the dung reference collection. However, analyses performed including fresh and ashed dung samples from the reference collection showed that the latter are clearly different from the ethnographic samples both in phytolith composition (Fig. 6a) and in phytolith and chemical composition (Fig. 6b). Further analyses were then performed excluding the reference collection of dung. These showed that there is some 
overlap between the four groups of samples (fireplaces, inner_control, outer_control and general floor). However, phytoliths alone (Fig. 7a) discriminate fireplaces, especially the two inner ones, from other samples, whereas phytoliths and chemical element results (Fig. $7 \mathrm{~b}$ ) contribute to a full discrimination between the fireplaces, also in the case of the veranda fireplace. Another important result is the clear separation between the fireplace samples and the outer_controls, whereas the inner_control samples cluster extremely close to the fireplaces.

Fig. 6

Plot of the principle component analyses (PCAs), a performed on phytolith data and $\mathbf{b}$ on phytolith and chemical data, including both ethnographic and dung reference collection samples. Ellipses are drawn automatically around the barycentre of the groups
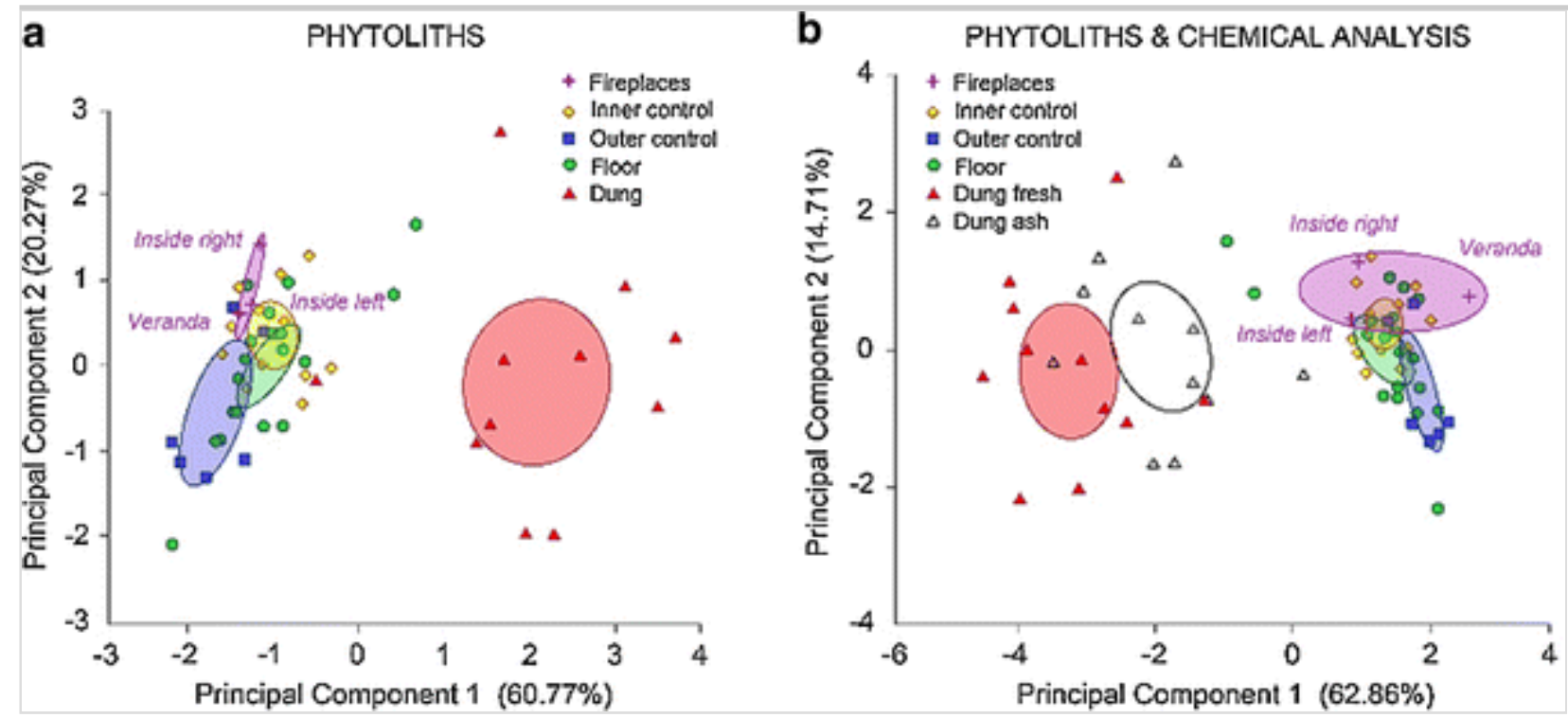

\section{Fig. 7}

Plot of principle component analyses (PCAs), a performed on phytolith data, and $\mathbf{b}$ on phytolith and chemical data from the ethnographic samples only, excluding the dung reference collection samples. Ellipses are drawn automatically around the barycentre of the groups 

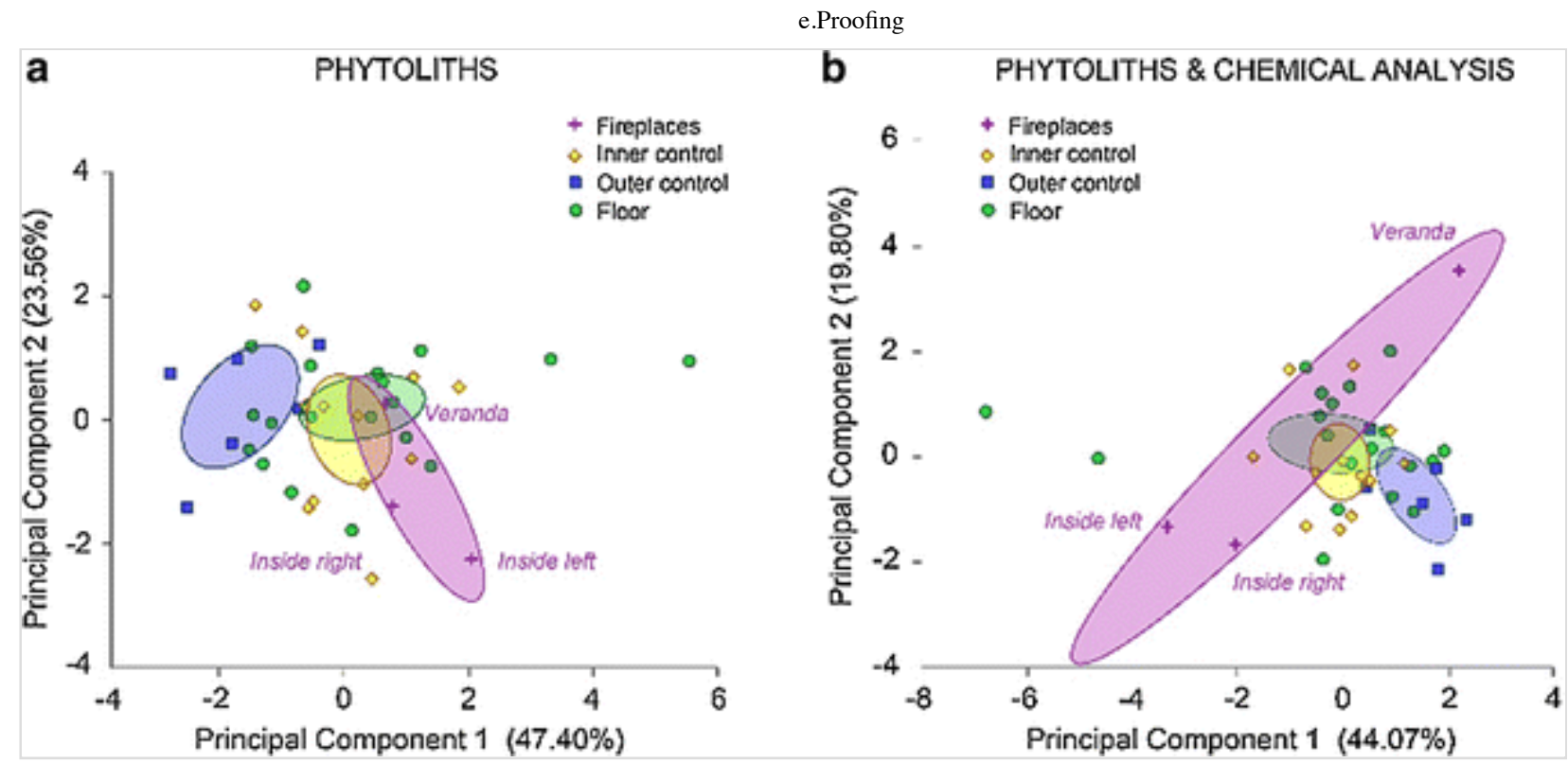

$\mathrm{AQ1}$

\section{Discussion}

Fire is one of the fundamental elements of human life and fuel one of the biggest issues of the modern world. Alternative fuels have been important not only in the past, but they continue to be a basic resource for rural households in arid and semi-arid regions worldwide (Viswanathan and Kumar 2005). In India, one of the most recent estimates of the value of dung as fuel was about 1.5 billion US dollars (Harris 2001). With the current trend in climate change at a global level and the increase in pressure on vegetation, it is to be expected that the value of alternative fuels will only increase. For this reason, unravelling the strategies which may have been used by past societies for fuel exploitation and use to deal with scarcity can offer precious hints on how to deal with some of the challenges of our modern way of life. In this perspective, it is important for the archaeologist to rely on robust and secure analytical and interpretative models when addressing the study of fuel use in the past. Wood charcoal remains have been one of the primary sources of information on past fuel use. However, in many archaeological contexts charcoal remains are not present, either due to post-depositional taphonomic processes or because wood was not the primary source of fuel. This is often the case in arid and semi-arid areas, where trees were scarce and alternative fuel sources needed to be exploited, such as dung, often in the form of dung cakes, and by-products of crop processing. 
In this work we show the value of ethnography as a support for data interpretation and methodological improvement. Previous work conducted in the same context had highlighted possible interpretation problems with an otherwise innovative and powerful methodology (Rondelli et al. 2014). With the present work we show that a multi-proxy approach with the integration of phytolith analysis and the application of multivariate statistics helps to address these challenges. The high concentration of graminoid phytoliths in all samples, together with the predominance of leaf or culm morphotypes, with small inputs from graminoid inflorescences as well as woody taxa highlights the homogeneity of the base material, dung (Lancelotti and Madella 2012), which is used in the study context as the main component of structures such as floors and walls. Therefore it is to be expected, as shown by the results, that both phytoliths and chemical elements display a high level of dung signatures (Table 1; Figs. 4, 5). Previous studies conducted on the dung reference material showed that phytolith and chemical composition of the dung cakes was independent of their site of collection (Lancelotti and Madella 2012). Therefore, the comparison of results with a modern dung reference collection was performed assuming that the floor samples would be closer to the fresh dung. It was thought that the fireplace samples where dung was used as fuel would cluster together with the ashed dung. However, the reference samples did not cluster with any of the ethnographic samples, suggesting that the stronger signal both in chemical elements and phytoliths was provided by a source other than dung. Nevertheless, there are important anomalies such as discontinuities in the data that provide anchors for the interpretation of the firing activities. It is important to notice that, in the case of phytoliths from within the centre of the fireplace, the actual use of the hearth plays a much more important role in the formation of the phytolith assemblage than the fuel used. In other words, the phytolith assemblages recovered from inside the fireplaces represent a short snapshot of the firing practices and indicate just the last one, or last few, burning episodes. This is valid for, and has been previously observed in wood charcoal studies (Chabal 1997). In this respect, the hearth located in the veranda, which was actually the one being used on the days when sampling was carried out, had the highest value of woody morphotypes even though the normal fuel used there was mainly a mixture of dung. Both the short-term nature of the fireplace deposit and the mixture of dung and wood fuel used in the veranda are 
corroborated by the chemical analyses and the high peak of both dung and wood ash elements found in this sample. As both groups include phosphorous, these high peaks are determined by the very high concentration of this element in the sample collected in the external fireplace.

In order to clearly understand fuel practices we suggest that, as phytoliths are concerned, an important role is played by the samples collected from the immediate surroundings of the fireplace. For example, interviews conducted with the family occupying the house indicated a preferential use of wood in the two hearths located inside the house, Inside_right and Inside_left. The fireplace sample showed few woody dicotyledonous morphotypes or none, whereas the control samples (both inner and outer) had a relatively high percentage.

These particular deposition patterns can be related to the high probability of ash being dispersed in the surroundings of the fireplace either during cooking or during the periodical cleaning of the hearth. As these are repetitive activities, they continuously deposit microremains on the floor, so an accumulation is produced that leaves a clear signature in the record. Indeed, even if the floor is also cleaned periodically, this activity affects the entire surface of the floor. Therefore, the anomalies in the deposition of phytoliths are not only preserved, but are also increased by the sweeping activities that contribute to spread the fuel residues around the fireplace itself.

Multivariate statistics performed on phytoliths and on both phytolith and chemical data suggest that although a certain degree of separation exists when all the groups of samples are considered together; no statistical differences are to be found between each fireplace and its controls. This corroborates the suggestion expressed above that the samples surrounding the actual firing contexts can help in the identification of fuel practices. The principle components analyses indicate, however, that only the control samples closer to the fireplace are representative of the fuel used, as the outer controls tend to form a separate cluster that does not overlap with the fireplaces.

As stated in the introduction, the primary scope of this paper is to test an analytical methodology in a controlled environment, where the results of the analyses can be calibrated against known activities. This will allow the safe 
application of this methodology to archaeological contexts where the original input of fuel and the specific use of fire installations are not known. Other factors, such as more pronounced taphonomic processes as well as stratigraphic and contextual uncertainty will need to be taken into consideration in archaeological settings. However, we consider that a multiproxy approach backed by sound statistical analyses represents the most effective method to address the above-mentioned issues.

\section{Conclusions}

We maintain that a quantitative and multi-proxy approach is necessary to correctly identify traces of fuel other than wood in archaeological contexts. Moreover, we propose that ethnography can be a powerful source of information, not only in the sense of tracing a direct parallel between modern and past practices, but also as a context in which to test hypotheses and methodologies. Indeed, only by comparing the results of our analytical work against contexts that are secure and on which we have exact information, can we fine-tune our interpretation of analytical results. This study shows how the integration of phytoliths and geochemical elements can contribute to our definition of fuel practices and how, in order to really grasp the full extent of fuel use in domestic contexts, researchers need to take into consideration not only the fireplace context but also the samples from its immediate surroundings.

\section{Acknowledgments}

All authors belong to the Complexity and Socio-Ecological Dynamics (CaSEs) Research Group, a Grup de Recerca Emergent (SGRe-1417) of the Generalitat de Catalunya, coordinated by Marco Madella. This research was carried out within the framework of the projects MoMArq (Spanish Ministry of Economy and Competitiveness, HAR2014-55518-P) and NoGAP (Ministry of Economy and Competitiveness HAR2010-16052 and CONSOLIDER INGENIO CSD2010-00034; the Spanish Ministry of Education, Culture and Sport through the Program Ayudas para Proyectos Arqueologicos en el Exterior 2009-2010; and the EXCAVA 2009 program of the Generalitat de Catalunya). 
JJGG was supported by a JAE PreDOC Doctoral Scholarship (Spanish National Research Council and European Fund). The authors are extremely grateful to all their Indian colleagues, especially Ajithprasad P. and Charusmita Gadekar for their invaluable help in the field. We also want to thank warmly Sakti-ji, Nemaji, Puri Sonal and Nita for welcoming us in their home, letting us make holes in their floor and being very patient with all our questions.

\section{Electronic supplementary material}

Below is the link to the electronic supplementary material.

Supplementary material 1 (XLSX $21 \mathrm{~kb})$

Supplementary material 2 (XLSX $19 \mathrm{~kb}$ )

Supplementary material 3 (XLSX $14 \mathrm{~kb}$ )

ESM 1 Results of the analysis of variance (ANOVA) and multivariate analysis of variance (MANOVA)

ESM 2 PCA results: eigenvalues, contribution of the variables (groups) and coordinates of individuals in each component for all samples (including dung reference collection)

ESM 3 PCA results: eigenvalues, contribution of the variables (groups) and coordinates of individuals in each component (excluding dung reference collection)

\section{References}

Albert RM, Weiner S (2001) Study of phytoliths in prehistoric ash layers from Kebara and Tabun caves using a quantitative approach. In: Meunier 
D, Colin F (eds) Phytoliths: applications in earth sciences and human history. CRC Press, Boca Raton, pp 251-266

Asouti E (2003) Woodland vegetation and fuel exploitation at the prehistoric campsite of Pinarbas1, south-central Anatolia, Turkey: the evidence from the wood charcoal macro-remains. J Archaeol Sci 30:1,1851,201

Barba L (1986) La química en el estudio de áreas de actividad. In: Manzanilla L (ed) Unidades habitacionales mesoamericanas y sus áreas de actividad. UNAM, Mexico City, pp 21-39

Beresford-Jones DG, Johnson K, Pullen AG, Pryor AJ, Svoboda J, Jones MK (2010) Burning wood or burning bone? A reconsideration of flotation evidence from upper Palaeolithic (Gravettian) sites in the Moravian corridor. J Archaeol Sci 37:2,799-2,811

Chabal L (1997) Forets et sociétés en Languedoc (Néolithique Final Antiquité Tardive). L'Anthracologie, méthode et paléoécologie. (Documents d'Archéologie Française 63) Maison de Sciences de l'homme, Paris

Friesem DE, Karkanas P, Tsartsidou G, Shahack-Gross R (2014) Sedimentary processes involved in mud brick degradation in temperate environments: a micromorphological approach in an ethnoarchaeological context in northern Greece. J Archaeol Sci 41:556-567

García-Granero JJ, Lancelotti C, Madella M (2015) A tale of multiproxies: integrating macro- and microbotanical remains to understand subsistence strategies. Veget Hist Archaeobot 24:121-133

Gur-Arieh S, Mintz E, Boaretto E, Shahack-Gross R (2013) An ethnoarchaeological study of cooking installations in rural Uzbekistan: development of a new method for identification of fuel sources. J Archaeol Sci 40:4,331-4,347

Harris M (2001) India's sacred cow. In: Goodman A, Dufur D, Pelto G 
(eds) Nutritional anthropology. Biocultural perspectives on food and nutrition. Mayfield Publishing Company, Mountain View, pp 113-118

Lancelotti C (2010) Fuelling Harappan hearths: human-environment interactions as revealed by fuel exploitation and use. Dissertation, University of Cambridge

Lancelotti C, Madella M (2012) The 'invisible' product: developing markers for identifying dung in archaeological contexts. J Archaeol Sci 39:953-963

Lê S, Josse J, Husson F (2008) FactoMiner: an R package for multivariate analysis. J Stat Softw 25:1-18

Linseele V, Riemer H, Baeten J, Vos DD, Marinova E, Ottoni C (2013) Species identification of archaeological dung remains: a critical review of potential methods. Environ Archaeol 18:5-17

Madella M, Powers-Jones AH, Jones MK (1998) A simple method of extraction of opal phytoliths from sediments using a non-toxic heavy liquid. J Archaeol Sci 25:801-803

Madella M, Ajithprasad P, Lancelotti C et al (2010) Social and environmental transitions in arid zones: the North Gujarat Archaeological Project-NoGAP. Antiquity Publications, Durham

Meyer J (2003) Understanding hearth function: an approach from Harappa. Asian Perspect 42:287-303

Middleton W, Barba L, Pecci A, Burton JH, Ortiz A, Salvini L, Suarez RR (2010) The study of archaeological floors: methodological proposal for the analysis of anthropogenic residues by spot tests, ICP-AES, and GC-MS. J Archaeol Method Theory 17:183-208

Pearsall DM, Piperno DR, Dinan EH, Umlauf M, Zhao Z, Benfer RA (2008) Distinguishing rice (Oryza sativa, Poaceae) from wild Oryza species through phytolith analysis: results of preliminary research. Econ 
Piperno DR (2006) Phytoliths. A comprehensive guide for archaeologists and paleoecologists. Altamira Press, Lanham

R Development Core Team (2014) R: a language and environment for statistical computing. R Foundation for Statistical Computing, Vienna

Rondelli B, Lancelotti C, Madella M et al (2014) Anthropic activity markers and spatial variability: an ethnoarchaeological experiment in a domestic unit of northern Gujarat (India). J Archaeol Sci 41:482-492

Shahack-Gross R (2011) Herbivorous livestock dung: formation, taphonomy, methods for identification, and archaeological significance. J Archaeol Sci 38:205-218

Shahack-Gross R, Marshall F, Ryan K, Weiner S (2004) Reconstruction of spatial organization in abandoned Maasai settlements: implications for site structure in the pastoral Neolithic of East Africa. J Archaeol Sci 31:1,3951,411

Théry-Parisot I (2002) Fuel management (bone and wood) during the lower Aurignacian in the Pataud rock shelter (lower Palaeolithic, Les Eyzies de Tayac, Dordogne, France) — contribution of experimentation. J Archaeol Sci 29:1,415-1,421

Viswanathan B, Kumar KK (2005) Cooking fuel use patterns in India: 1983-2000. Energy Policy 33:1,021-1,036

Yannitto V (2011) Micromorfología en contexto etnoarqueologico. Técnicas constructivas entre los agricultores de Jandhala (Gujarat, India). Dissertation, Autonomous University of Barcelona

Zapata Peña L, Peña Chocarro L, Ibañez Estévez JJ, González Urquijo EJ (2003) Ethnoarchaeology in the Moroccan Jebala (Western Rif): wood and dung as fuel. In: Neumann K (ed) Food, fuels and fields: progress in African archaeobotany (Africa Praehistorica 15). Heinrich Barth Institut, 
Köln, pp 163-175

Zurro D (2011) Ni carne ni pescado (consumo de recursos vegetales en la Prehistoria): Análisis de la variabilidad de los conjuntos fitolitologicos en contextos cazadores-recolectores. Dissertation, Universitat Autonoma de Barcelona 